\title{
DIAGNOSIS of ENDOCRINE DISEASE: SDHX mutations: beyond pheochromocytomas and paragangliomas
}

\author{
Massimo Mannelli', Letizia Canu', Tonino Ercolino', Elena Rapizzi², \\ Serena Martinelli', Gabriele Parenti ${ }^{3}$, Giuseppina De Filpo ${ }^{1}$ and Gabriella Nesi ${ }^{4}$ \\ ${ }^{1}$ Department of Experimental and Clinical Biomedical Sciences and, ${ }^{2}$ Department of Experimental and Clinical \\ Medicine, University of Florence, Florence, Italy, ${ }^{3}$ Azienda Ospedaliera-Universitaria Careggi, Florence, Italy, and \\ ${ }^{4}$ Department of Surgery and Translational Medicine, University of Florence, Florence, Italy
}

Correspondence should be addressed to M Mannelli Email massimo.mannelli@unifi.it

\begin{abstract}
Mutations in one of the five genes encoding the succinate dehydrogenase (SDHx) or mitochondrial complex II cause the corresponding family syndromes characterized by the occurrence of pheochromocytomas (PHEO) and paragangliomas (PGL). Recently, other solid growths, such as gastrointestinal stromal tumors (GISTs), renal cell carcinomas (RCCs) and pituitary adenomas (PAs) have been associated with these syndromes. In the absence of prospective studies assessing their frequency, at present, their occurrence seems too infrequent to suggest systematic screening for SDHx mutation carriers. However, SDHB immunohistochemistry (IHC) on tumor tissues or SDHx genetic testing on blood or tumor samples should be performed in patients affected by GISTs, RCCS or PAs with clinicopathologic phenotypes suggesting an etiologic role of SDHx genes.
\end{abstract}

\section{Introduction}

Pheochromocytomas (PHEO) and paragangliomas (PGL) are rare neural crest-derived tumors $(1,2)$. They comprise adrenal and extra-adrenal chromaffin, sympathetic, catecholamine releasing tumors, namely secreting PGL (sPGL) and tumors of the parasympathetic ganglia in the head and neck region, namely head and neck PGL (HNPGL). These tumors are the most common heritable tumors recorded to date $(3,4)$. Approximately $35 \%$ of them are caused by germline mutations and an additional $10-15 \%$ show somatic mutations in the same or other susceptibility genes, which include those encoding the succinate dehydrogenase (SDH) or mitochondrial complex II (5).

SDH is functionally involved in both the Krebs cycle, where it transforms succinate into fumarate, and the electron transport chain. The complex consists of four structural subunits: two hydrophilic catalytic subunits,

www.eje-online.org https://doi.org/101530/EJE-17-0523
() 2018 European Society of Endocrinology Printed in Great Britain
$\mathrm{A}$ and $\mathrm{B}$, encoded by the corresponding $S D H A$ and $S D H B$ genes and two hydrophobic subunits, $\mathrm{C}$ and $\mathrm{D}$, encoded by $S D H C$ and SDHD genes anchoring the catalytic subunits to the inner mitochondrial membrane (6). Enzymatic activity requires a functional unit, succinate dehydrogenase complex assembly factor 2 (SDHAF2), responsible for flavination of the catalytic subunit $\mathrm{A}$ and encoded by the corresponding SDHAF2 gene (7).

Mutations in any of these five genes cause disassembly of the mitochondrial complex, with loss of SDH enzymatic activity $(8,9)$ as well as of SDHB expression at immunohistochemistry (IHC) while SDHA is lost, together with SDHB, in SDHA-mutated tumors, but its expression is retained in tumors with other SDH mutations.

Consequently, SDHB IHC (10) has been assumed as a rapid and inexpensive preliminary test on tumor tissue to investigate on tumor's SDH insufficiency. 
Mutations in any of these five genes cause impairment of SDH enzymatic activity and loss of SDHB expression, whereas loss of SDHA expression is only detected in SDHA mutations $(8,9)$. SDH immunohistochemistry (IHC) has therefore become a rapid and inexpensive tool for testing SDH insufficiency in tumor tissue (10).

Mutations in any of the five SDH genes are responsible for the occurrence of PHEO/PGL.

In 2000, Baysal et al. (5) demonstrated that SDHD mutations result in an inherited familial syndrome, known as familial paragangliomatosis type 1 (PGL1) characterized by the presence of both SPGL and HNPGL (11). Subsequently, other $S D H x$ genes also proved to be PHEO/PGL susceptibility genes $(12,13,14,15)$, and their germline mutations are associated with the corresponding familial syndromes, namely PGL2 to PGL5 (Table 1). The clinical picture of these five PGL syndromes differs in some aspects, but they are all characterized by the presence of PHEO/PGL $(16,17,18,19,20)$.

In recent years, germline mutations in $\mathrm{SDHx}$ genes have been rarely associated with other solid tumors beyond PHEO/PGL, such as gastrointestinal stromal tumors (GISTs) (21), renal cell carcinomas (RCC) (22) and pituitary adenomas (PAs) (23). To our knowledge, no systematic prospective study has been conducted in $S D H x$ mutation carriers to define the true prevalence of solid tumors other than PHEO/PGL. These additional solid tumors have been sometimes found incidentally in SDHx mutation carriers and most of the papers evaluating the role of SDH in the pathogenesis of these tumors report retrospective studies performed by SDHB IHC on paraffinembedded tumor tissue. Tumors have been labeled as 'SDH deficient' in case of negative SDHB immunostaining but not all the tumors or the patients have then undergone genetic analysis looking for the correspondent $S D H x$ somatic or germline mutations.

This paper reviews these tumors and their characteristics.

\section{Gastrointestinal stromal tumors (GISTs)}

GISTs are the most common mesenchymal tumors of the gastrointestinal tract (24), occurring as sporadic or familial with an incidence of $6.8-20$ per million $(25,26,27)$.

In $85-90 \%$ of cases, GISTs result from activating mutations of KIT or PDGFRA genes $(28,29)$. The other $10-15 \%$ non-KIT/PDGFRA-mutated GISTs, incorrectly labeled as 'wild type', mainly affect children. Mutations in NF1 $(30,31)$ or BRAF (32) genes account for $50 \%$ of these cases, while the remaining $50 \%$ prove negative for SDHB on IHC, and are referred to as SDH-deficient GISTs. They can be sporadic or part of two syndromes, i.e. Carney-Stratakis (33) syndrome and Carney triad (34). In Carney-Stratakis syndrome, dominantly inherited and due to germline SDHx mutations, GISTs are associated with PGL $(35,36)$, whereas they are associated with PGL and pulmonary chondromas in Carney triad.

Etiology of Carney triad is uncertain (37). Comparative genomic hybridization has shown alterations in the 1q, $1 \mathrm{p}$ and less frequently in the $14 \mathrm{q}$ and $22 \mathrm{q}$ chromosomal loci (38). Although $S D H B$ is located on chromosome 1p36.1-p35 and $S D H C$ on 1q21-q23.3, germline mutations of $S D H x$ genes have rarely been found. Nonetheless, the

Table 1 Clinical characteristics of the SDHx-related syndromes.

\begin{tabular}{|c|c|c|c|c|c|c|}
\hline Gene & Lesions & Multiple lesions & Penetrance & Malignancy & Paternaltransmission & Associated neoplasms \\
\hline$S D H D$ & HNPGL & Yes & High & Very rare & Yes & GIST \\
\hline \multirow[t]{3}{*}{ PGL1 } & Thoracic PGL & & & & & PA \\
\hline & Abdominal PGL & & & & & $\mathrm{RCC}$ \\
\hline & PHEO & & & & & PTC (?) \\
\hline$S D H B$ & Abdominal PGL & Yes (rare) & Low & Frequent & No & GIST \\
\hline \multirow{3}{*}{ PGL4 } & HNPGL & & & & & $\mathrm{RCC}$ \\
\hline & PHEOs & & & & & PA \\
\hline & & & & & & PTC (?) \\
\hline$S D H C$ & HNPGL & Rare & Unknown & Unknown & No & GIST \\
\hline \multirow[t]{2}{*}{ PGL3 } & Abdominal PGL & & & & & $\mathrm{RCC}$ \\
\hline & & & & & & PA \\
\hline SDHAF2 & HNPGL & Rare & Unknown & Unknown & Yes & PA \\
\hline \multicolumn{7}{|l|}{ PGL2 } \\
\hline SDHA & Abdominal PGL & Rare & Unknown & Unknown & No & GIST \\
\hline PGL5 & & & & & & PA \\
\hline
\end{tabular}

HNPGL, head and neck paragangliomas; PA, Pituitary adenoma; PHEO, pheochromocytomas; PGL, paragangliomas; PTC, Papillary Thyroid Carcinoma; RCC, Renal cell carcinoma. 
GISTs from Carney triad display loss of immunoreactivity for SDHB (39). This finding can be explained by SDHx somatic losses or by epigenetic silencing of SDHC promoter (40).

SDH-deficient GISTs account for $5-7.5 \%$ of all GISTs. Nearly all are located in the stomach, usually multiple, and frequently multinodular, they may metastasize to lymph nodes, but generally present a protracted and indolent course $(35,37,41)$.

In summary, GISTs occur rarely in SDHx mutation carriers and therefore systematic screening for these tumors does not seem to be cost-effective. However, in the case of a GIST showing characteristics such as childhood onset, gastric location, multiple lesions, nodular/plexyform histology or a positive personal or family history for PHEO/PGL, SDHB immunostaining of the tumor or SDHx genetic testing on patient or tumor DNA should be performed. Indeed, the diagnosis of a familial form has important consequences on the clinical management of the patient and of his/her family members.

\section{Renal cell carcinomas (RCCs)}

SDHx mutated RCCs are rare tumors, estimated to account for $0.05-0.2 \%$ of all RCCs (42). The first report on SDHBmutated patients affected by both PHEO/PGL and RCCs was by Vanharanta et al. in 2004 (22). The renal cancers diagnosed in these $S D H B$ mutation carriers appeared to originate from the epithelial cells of the proximal tubule and were composed of a mixture of clear cells and cells with granular-eosinophilic cytoplasm arranged in a variably solid or nested architecture.

In a more recent paper, Gill et al. evaluated the morphology of 36 SDH-deficient RCCs from 27 patients and concluded that the most distinctive histologic feature was the presence of cytoplasmic vacuoles and inclusionlike spaces containing either pale eosinophilic fluid or flocculent material (42). Nonetheless, in some cases, these inclusions were focal and not easy to identify. Ricketts et al. also reported that in 21 cases of SDH-deficient RCC, most tumors exhibited 'oncocytic' features although renal tumor histology was variable (43).

SDH-deficient RCC has been recognized as novel entity in the 2016 WHO classification of renal tumors $(44,45)$. It may show a morphologic spectrum wider than has been previously described (46) and some cases may be essentially indistinguishable from other non-SDH-related RCCs at histology. Of the SDH-deficient RCCs, the most common are those due to $S D H B$ mutations.
According to Gill (42), SDH-deficient RCCs commonly present at a mean age of 37 years (range 14-76) while in the series of Williamson (47), the mean age is 40 years (range 22-72). Multifocal or bilateral tumors are detected in $30 \%$ of patients at long-term follow-up.

In summary, the very low prevalence of SDH-deficient RCCs seems to make their systematic research non-costeffective in SDHx mutation carriers. SDH IHC or SDHx genetic testing should however be considered in RCCs occurring in patients younger than 40 years, as multiple or recurrent tumors, or in the case of a positive personal or family history of PHEO/PGL, GISTs or RCCs.

\section{Pituitary adenomas (PAs)}

The first report of an $S D H$ (in this case $C$ ) mutation carrier affected by a single HNPGL and a PA was by Lopez-Jimenez et al. in 2008 (48). The authors found loss of heterozygosity (LOH) in the HNPGL but could not verify SDH deficiency of the PA since the tumor tissue was not available. The first description of PAs related to an $S D H$ (in this case D) mutation was by Xekouki et al. in 2012 (23). They published the case of a 37-year-old male SDHD mutation carrier who presented multiple PGL in the neck, thorax and abdomen and a GH-secreting PA exhibiting $\mathrm{LOH}$ and downregulation of SDHD protein at immunoblotting and IHC. In 2013, Dwight et al. reported a case of PA arising in the setting of germline SDHA mutation (49).

In 2014 Gill et al. (50) immunohistochemically assessed 309 PAs detecting only one SDHA-negative PA as the result of a double SDHA somatic mutation. Subsequently, Xekouki et al. (51) performed genetic testing on 168 patients affected by PA, of which 146 were sporadic and 22 were familial.

Among the patients with sporadic PAs, 3 also displayed PHEO/PGL, but none of them was an SDHx mutation carrier. Conversely, in the group of patients with familial PAs, 4 also presented PHEO/PGL, 2 were SDHB and 1 SDHD germline mutation carriers.

To the best of our knowledge, 74 patients affected by both PHEO/PGL and PA have been reported so far $(52,53)$. Of the 72 patients collectively analyzed by O'Toole et al. (52), 23 (32\%) harbored no mutations but had a personal or family history suggestive of a hereditary endocrine syndrome, 28 (39\%) had no mutations and no suggestive personal or family history and $21(29 \%)$ were found to be mutated for a susceptibility gene, such as menin (4 patients), RET (1 patient), SDHB (6 patients), SDHD (5 patients), SDHC (1 patient) and SDHAF2 (1 patient). 
The patient age at diagnosis ranged from 15 to 84 years with a mean of 44 years. Of the 72 patients, 34 (47.2\%) presented a macroadenoma, 11 (15.3\%) a microadenoma and in 27 (37.5\%), the size of the PA was unavailable.

PA secretion varied but consisted mainly of $\mathrm{GH}$ (27patients, 37.5\%) and PRL (23 patients 31.9\%). Overall, $13(18.1 \%)$ patients had a non-functioning PA, $2(2.8 \%)$ an ACTH-secreting tumor and 1 (1.4\%) a mixed GH/PRLsecreting adenoma. In 1 (1.4\%) patient, PA was diagnosed as chromophobic, and in 5 (6.9\%), the secretion was not determined.

In summary, the occurrence of PAs in SDH germline mutation carriers is rare, and systematic screening does not seem to be recommended. Conversely, $S D H x$ genetic testing or SDHB IHC is advisable in the case of familial PAs, phenotypically aggressive and/or therapy-resistant PAs, early-onset PAs or patients with a positive personal or family history for PHEO/PGL.

\section{Other tumors}

In addition to GISTs, RCCs and PAs, other tumors have been reported to be associated with PHEO/PGL in SDHx germline mutation carriers; however, very few cases have been found to be related to SDH deficiency.

In 2004, Neumann et al. (16) reported the occurrence of papillary thyroid carcinoma (PTC) in one out of 53 SDHB mutation carriers and in one out of 47 SDHD mutation carriers, although the tumor SDH dependency was not investigated.

The causal role of SDH in differentiated thyroid cancers (DTC) was evaluated by Ni et al. (54) in 754 cases. Germline SDHx missense variants were found in 48 (6\%) patients, but were generally classified as non-pathogenic. However, papillary and follicular thyroid tumors showing consistent loss of SDHC/D gene expression were associated with earlier disease onset and higher pathologic stage. Although these findings identify SDHx as modifier genes in the clinical presentation of DTC, Papathomas et al. argued against a positive link between PTC and SDHdeficient state (55). Indeed, all the 60 cases of PTC under study proved immunoreactive for SDHB. Similarly, the authors did not find any SDHB-negative tumor among 47 neuroblastic tumors, 50 testicular seminomas and 10 adenomatoid adrenal tumors.

An association between SDHx mutations and lymphoid malignancies has been recently reported by Renella et al. (56) in two families. In one family, a young female $S D H B$ mutation carrier was affected with abdominal
PGL and nodular lymphocyte-predominant Hodgkin lymphoma staining for SDHB. The pedigree of the other family included a 15-year-old SDHC mutation carrier with metastatic GIST/PHEO and a 24-year-old maternal aunt diagnosed with stage IV-B Hodgkin lymphoma whose specimen was not available for IHC.

Finally, a pancreatic neuroendocrine tumor showing SDHB negativity, SDHA positivity and $\mathrm{LOH}$ has been reported in an SDHD mutation carrier who was also affected with oligodendroglioma and multiple HNPGL (53).

\section{Discussion}

In addition to $\mathrm{PHEO} / \mathrm{PGL}, \mathrm{SDHx}$ gene mutations are responsible for the occurrence of other solid tumors, mainly GISTs, RCCs and PAs.

The frequency of these non-neural-crest-derived tumors seems to be very rare, although the cases reported in the literature may result underestimated as no systematic studies aimed at diagnosing these tumors have been performed in SDHx mutation carriers. Nevertheless, SDHx mutation carriers are generally (and hopefully) enrolled in a lifelong screening looking for the occurrence of HNPGL as well as of PHEO/PGL and therefore tumors like RCC and PA should be diagnosed during radiological screening procedures, by CT or MRI, carried out on the abdomen or head and neck respectively.

Therefore, at present, a systematic search for neoplasms other than PHEO/PGL in SDHx mutation carriers does not seem advisable although prospective studies aimed at establish their frequency are necessary. Nevertheless, these tumors may at times present clinical or histologic features suggestive of $S D H x$ dependency, thereby recommending SDHB IHC on tumor tissue or SDHx genetic testing on patient's blood or tumor DNA. However, when testing tumor tissue by IHC, it must be recalled that SDHB IHC should be interpreted with caution, due to possible false positive (i.e. positive or weakly diffuse SDHB staining) sometimes observed in SDHD-mutated tumors (57). As a whole, a negative SDHB immunostaining proves that the tumor depends on a loss of SDH expression. This result should then be confirmed by genetic analysis on blood and/or tumor DNA to detect the type of mutation and whether the mutation is germline or somatic. When available, tumor DNA analysis for SDHx mutations should be performed for first. Other tools aimed at proving tumor SDH impairment are SDHB expression by western blot analysis or the measurement of SDH activity in tumor tissue. 
Finally, in spite of the low frequency of tumors other than PHEO/PGL, when screening SDHx mutation carriers clinicians should accurately inquire on signs or symptoms associated to GISTs, RCCs or PAs. Conversely, in patients affected by GISTs, RCCs or Pas, clinicians should collect an accurate personal and family history searching for the occurrence of PHEO/PGL. Indeed, the diagnosis of a genetic syndrome is clinically relevant both for the index case as well as for the family members.

\section{Declaration of interest}

The authors declare that there is no conflict of interest that could be perceived as prejudicing the impartiality of the review reported.

\section{Funding}

This work was supported by the Paradifference Foundation and by the Fondazione Cassa di Risparmio di Pistoia e Pescia (Prot. 2016.0241/gi) to M M; L C, T E, E R, S M and M M are members of the ENS@T (European Network for the Study of Adrenal Tumors).

\section{References}

1 Lenders JW, Eisenhofer G, Mannelli M \& Pacak K. Phaeochromocytoma. Lancet 2005366 665-675. (https://doi. org/10.1016/S0140-6736(05)67139-5)

2 Manger WM. An overview of pheochromocytoma: history, current concepts, vagaries, and diagnostic challenges. Annals of the New York Academy of Sciences 20061073 1-20. (https://doi.org/10.1196/ annals.1353.001)

3 Dahia P. Pheochromocytoma and paraganglioma pathogenesis: learning from genetic heterogeneity. Nature Reviews Cancer 201414 108-119. (https://doi.org/10.1038/nrc3648)

4 Welander J, Soderkvist P \& Gimm O. Genetics and clinical characteristics of hereditary pheochromocytomas and paragangliomas. Endocrine-Related Cancer 201118 R253-R276. (https://doi.org/10.1530/ERC-11-0170)

5 Baysal BE, Ferrell RE, Willett-Brozick JE, Lawrence EC, Myssiorek D, Bosch A, van der Mey A, Taschner PE, Rubinstein WS, Myers EN et al. Mutations in SDHD, a mitochondrial complex II gene, in hereditary paraganglioma. Science 2000287 848-851. (https://doi.org/10.1126/ science.287.5454.848)

6 Cecchini G. Respiratory complex II: role in cellular physiology and disease. Biochimica and Biophysica Acta (BBA): Bioenergetics 20131827 541-542. (https://doi.org/10.1016/j.bbabio.2013.02.010)

7 Ghezzi D, Goffrini P, Uziel G, Horvath R, Klopstock T, Lochmüller H, D'Adamo P, Gasparini P, Strom TM, Prokisch H et al. SDHAF1, encoding a LYR complex-II specific assembly factor, is mutated in SDHdefective infantile leukoencephalopathy. Nature Genetics 200941 654-656. (https://doi.org/10.1038/ng.378)

8 Gimenez-Roqueplo AP, Favier J, Rustin P, Mourad JJ, Plouin PF, Corvol P, Rotig A \& Jeunemaitre X. The R22X mutation of the SDHD gene in hereditary paraganglioma abolishes the enzymatic activity of complex II in the mitochondrial respiratory chain and activates the hypoxia pathway. American Journal of Human Genetics 200169 1186-1197. (https://doi.org/10.1086/324413)

9 Rapizzi E, Ercolino T, Canu L, Giaché V, Francalanci M, Pratesi C, Valeri A \& Mannelli M. Mitochondrial function and content in pheochromocytoma/paraganglioma of succinate dehydrogenase mutation carriers. Endocrine-Related Cancer 201219 261-269. (https:// doi.org/10.1530/ERC-11-0263)

10 Van Nederveen FH, Gaal J, Favier J, Korpershoek E, Oldenburg RA, De Bruyn EM, Sleddens HF, Derkx P, Rivière J, Dannenberg H et al. An immunohhistochemical procedure to detect patients with paraganglioma and pheochromocytoma with germline SDHB, SDHC, or SDHD gene mutations: a retrospective and prospective analysis. Lancet Oncology 200910 764-771. (https://doi.org/10.1016/S14702045(09)70164-0)

11 Simi L, Sestini R, Ferruzzi P, Gaglianò MS, Gensini F, Mascalchi M, Guerrini L, Pratesi C, Pinzani P, Nesi G et al. Phenotype variability of neural crest derived tumours in six Italian families segregating the same founder SDHD mutation Q109X. Journal of Medicine Genetics 200542 e52. (https://doi.org/10.1136/jmg.2004.030353)

12 Niemann S \& Muller U. Mutations in SDHC cause autosomal dominant paraganglioma, type 3. Nature Genetics 200026 268-270. (https://doi.org/10.1038/81551)

13 Astuti D, Latif F, Dallol A, Dahia PL, Douglas F, George E, Sköldberg F, Husebye ES, Eng C \& Maher ER. Gene mutations in the succinate dehydrogenase subunit SDHB cause susceptibility to familial pheochromocytoma and to familial paraganglioma. American Journal of Human Genetics 200169 49-54. (https://doi.org/10.1086/321282)

14 Hao HX, Khalimonchuk O, Schraders M, Dephoure N, Bayley JP, Kunst H, Devilee P, Cremers CW, Schiffman JD, Bentz BG et al. SDH5, a gene required for flavination of succinate dehydrogenase, is mutated in paraganglioma. Science 2009325 1139-1142. (https://doi. org/10.1126/science.1175689)

15 Burnichon N, Brière JJ, Libé R, Vescovo L, Rivière J, Tissier F, Jouanno E, Jeunemaitre X, Bénit P, Tzagoloff A et al. SDHA is a tumor suppressor gene causing paraganglioma. Human Molecular Genetics 201019 3011-3020. (https://doi.org/10.1093/hmg/ddq206)

16 Neumann HP, Pawlu C, Peczkowska M, Bausch B, McWhinney SR, Muresan M, Buchta M, Franke G, Klisch J, Bley TA et al. Distinct clinical features of paraganglioma syndromes associated with SDHB and SDHD gene mutations. JAMA 2004292 943-951. (https://doi. org/10.1001/jama.292.8.943)

17 Burnichon N, Rohmer V, Amar L, Herman P, Leboulleux S, Darrouzet V, Niccoli P, Gaillard D, Chabrier G, Chabolle F et al. The succinate dehydrogenase genetic testing in a large prospective series of patients with paragangliomas. Journal of Clinical Endocrinology and Metabolism 200994 2817-2827. (https://doi.org/10.1210/jc.20082504)

18 Ricketts CJ, Forman JR, Rattenberry E, Bradshaw N, Lalloo F, Izatt L, Cole TR, Armstrong R, Kumar VK, Morrison PJ et al. Tumor risks and genotype-phenotype-proteotype analysis in 358 patients with germline mutations in SDHB and SDHD. Human Mutation 201031 41-51. (https://doi.org/10.1002/humu.21136)

19 Benn DE, Gimenez-Roqueplo AP, Reilly JR, Bertherat J, Burgess J, Byth K, Croxson M, Dahia PL, Elston M, Gimm O et al. Clinical presentation and penetrance of pheochromocytoma/paraganglioma syndromes. Journal of Clinical Endocrinology and Metabolism 200691 827-836. (https://doi.org/10.1210/jc.2005-1862)

20 Mannelli M, Castellano M, Schiavi F, Filetti S, Giacchè M, Mori L, Pignataro V, Bernini G, Giachè V, Bacca A et al. Clinically guided genetic screening in a large cohort of italian patients with pheochromocytomas and/or functional or nonfunctional paragangliomas. Journal of Clinical Endocrinology and Metabolism 2009 94 1541-1547. (https://doi.org/10.1210/jc.2008-2419)

21 McWhinney SR, Pasini B \& Stratakis CA. Familial gastrointestinal stromal tumors and germ-line mutations. New England Journal of Medicine 2007357 1054-1056. (https://doi.org/10.1056/ NEJMc071191)

22 Vanharanta S, Buchta M, McWhinney SR, Virta SK, Peczkowska M, Morrison CD, Lehtonen R, Januszewicz A, Jarvinen H, Juhola M et al. Early-onset renal cell carcinoma as a novel extraparaganglial 
component of $S D H B$-associated heritable. Paraganglioma. American Journal of Human Genetics 200474 153-159. (https://doi. org/10.1086/381054)

23 Xekouki P, Pacak K, Almeida M, Wassif CA, Rustin P, Nesterova M, de la Luz Sierra M, Matro J, Ball E, Azevedo M et al. Succinate dehydrogenase (SDH) D subunit (SDHD) inactivation in a growthhormone-producing pituitary tumor: a new association for SDH? Journal of Clinical Endocrinology and Metabolism 201297 E357-E366. (https://doi.org/10.1210/jc.2011-1179)

24 Corless CL, Fletcher JA \& Heinrich MC. Biology of gastrointestinal stromal tumors. Journal of Clinical Oncology 200422 3813-3825. (https://doi.org/10.1200/JCO.2004.05.140)

25 Perez EA, Livingstone AS, Franceschi D, Rocha-Lima C, Lee DJ, Hodgson N, Jorda M \& Koniaris LG. Current incidence and outcomes of gastrointestinal mesenchymal tumors including gastrointestinal stromal tumors. Journal of the American College of Surgeons 2006202 623-629. (https://doi.org/10.1016/j.jamcollsurg.2006.01.002)

26 Nilsson B, Bümming P, Meis-Kindblom JM, Odén A, Dortok A, Gustavsson B, Sablinska K \& Kindblom L-G. Gastrointestinal stromal tumors: the incidence, prevalence, clinical course, and prognostication in the preimatinib mesylate era-a population-based study in western Sweden. Cancer 2005103 821-829. (https://doi. org/10.1002/cncr.20862)

27 Tryggvason G, Gíslason HG, Magnússon MK \& Jónasson JG. Gastrointestinal stromal tumors in Iceland, 1990-2003: the icelandic GIST study, a population-based incidence and pathologic risk stratification study. International Journal of Cancer 2005117 289-293. (https://doi.org/10.1002/ijc.21167)

28 Hirota S, Isozaki K, Moriyama Y, Hashimoto K, Nishida T, Ishiguro S, Kawano K, Hanada M, Kurata A, Takeda M et al. Gain-of-function mutations of c-kit in human gastrointestinal stromal tumors. Science 1998279 577-580. (https://doi.org/10.1126/science.279.5350.577)

29 Heinrich MC, Corless CL, Duensing A, McGreevey L, Chen C-J, Joseph N, Singer S, Griffith DJ, Haley A, Town A et al. PDGFRA activating mutations in gastrointestinal stromal tumors. Science 2003 299 708-710. (https://doi.org/10.1126/science.1079666)

30 Rubin BP. Gastrointestinal stromal tumours: an update. Histopathology 200648 83-96. (https://doi.org/10.1111/j.13652559.2005.02291.x)

31 Maertens O, Prenen H, Debiec-Rychter M, Wozniak A, Sciot R, Pauwels P, De Wever I, Vermeesch JR, de Raedt T, De Paepe A et al. Molecular pathogenesis of multiple gastrointestinal stromal tumors in NF1 patients. Human Molecular Genetics 200615 1015-1023. (https://doi.org/10.1093/hmg/ddl016)

32 Agaram NP, Wong GC, Guo T, Maki RG, Singer S, Dematteo RP, Besmer P \& Antonescu CR. Novel V600E BRAF mutations in imatinib-naïve and imatinib-resistant gastrointestinal stromal tumors. Genes, Chromosomes and Cancer 200847 853-859. (https:// doi.org/10.1002/gcc.20589)

33 Carney JA \& Stratakis CA. Familial paraganglioma and gastric stromal sarcoma: a new syndrome distinct from the Carney triad. American Journal of Human Genetics $2002 \mathbf{1 0 8} 132-139$.

34 Carney JA, Sheps SG, Go VL \& Gordon H. The triad of gastric leiomyosarcoma, functioning extra-adrenal paraganglioma and pulmonary chondroma. New England Journal of Medicine 1977296 1517-1518. (https://doi.org/10.1056/NEJM197706302962609)

35 Janeway KA, Kim SY, Lodish M, Nosé V, Rustin P, Gaal J, Dahia PLM, Liegl B, Ball ER, Raygada M et al. Defects in succinate dehydrogenase in gastrointestinal stromal tumors lacking KIT and PDGFRA mutations. PNAS 2011108 314-318. (https://doi.org/10.1073/ pnas.1009199108)

36 Pasini B, McWhinney SR, Bei T, Matyakhina L, Stergiopoulos S, Muchow M, Boikos SA, Ferrando B, Pacak K, Assie G et al. Clinical and molecular genetics of patients with the Carney-Stratakis syndrome and germline mutations of the genes coding for the succinate dehydrogenase subunits SDHB, SDHC, and SDHD. European
Journal of Human Genetics 200816 79-88. (https://doi.org/10.1038/ sj.ejhg.5201904)

37 Boikos SA \& Stratakis CA. The genetic landscape of gastrointestinal stromal tumor lacking KIT and PDGFRA mutations. Endocrine 2014 47 401-408. (https://doi.org/10.1007/s12020-014-0346-3)

38 Matyakhina L, Bei TA, McWhinney SR, Pasini B, Cameron S, Gunawan B, Stergiopoulos SG, Boikos S, Muchow M, Dutra A et al. Genetics of carney triad: recurrent losses at chromosome 1 but lack of germline mutations in genes associated with paragangliomas and gastrointestinal stromal tumors. Journal of Clinical Endocrinology and Metabolism 200792 2938-2943. (https://doi.org/10.1210/jc.20070797)

39 Gaal J, Stratakis CA, Carney JA, Ball ER, Korpershoek E, Lodish MB, Levy I, Xekouki P, van Nederveen FH, den Bakker MA et al. SDHB immunohistochemistry: a useful tool in the diagnosis of Carney-Stratakis and Carney triad gastrointestinalstromal tumors. Modern Pathology 201124 147-151. (https://doi.org/10.1038/ modpathol.2010.185)

40 Haller F, Moskalev EA, Faucz FR, Barthelmess S, Wiemann S, Bieg M, Assie G, Bertherat J, Schaefer IM, Otto C et al. Aberrant DNA hypermethylation of SDHC: a novel mechanism of tumor development in Carney triad. Endocrine-Related Cancer 201421 567-577. (https://doi.org/10.1530/ERC-14-0254)

41 Zhang L, Smyrk TC, Young WF, Stratakis CA \& Carney JA. Gastric stromal tumors in Carney triad are different clinically, pathologically, and behaviorally from sporadic gastric gastrointestinal stromal tumors: findings in 104 cases. American Journal of Surgical Pathology 201034 53-64. (https://doi.org/10.1097/PAS.0b013e3181c20f4f)

42 Gill AJ, Hes O, Papathomas T, Šedivcová M, Tan PH, Agaimy A, Andresen PA, Kedziora A, Clarkson A, Toon CW et al. Succinate dehydrogenase (SDH)-deficient renal carcinoma: a morphologically distinct entity: a clinicopathologic series of 36 tumors from 27 patients. American Journal of Surgical Pathology 201438 1588-1602. (https://doi.org/10.1097/PAS.0000000000000292)

43 Ricketts CJ, Shuch B, Vocke CD, Metwalli AR, Bratslavsky G, Middelton L, Yang Y, Wei MH, Pautler SE, Peterson J et al. Succinate Dehydrogenase Kidney Cancer (SDH-RCC): an aggressive example of the Warburg effect in cancer. Journal of Urology 2012188 2063-2071. (https://doi.org/10.1016/j.juro.2012.08.030)

44 Gill A, Amin MB, Smith S \& Trpkov K. Succinate dehydrogenasedeficient renal carcinoma. In WHO Classification of Tumors of the Kidney, Bladder and Male Genital Tract. Eds H Moch \& PE Humphrey. Lyon: IARC Press. 2004

45 Srigley JR, Delahunt B, Eble JN, Egevad L, Epstein JI, Grignon D, Hes $\mathrm{O}$, Moch H, Montironi R, Tickoo SK et al. The International Society of Urological Pathology (ISUP) Vancouver classification of renal neoplasia. American Journal of Surgical Pathology 201337 1469-1489. (https://doi.org/10.1097/PAS.0b013e318299f2d1)

46 Kuroda N, Yorita K, Nagasaki M, Harada Y, Ohe C, Jeruc J, Raspollini MR, Michal M, Hes O \& Amin MB. Succinate Dehydrogenase Kidney Cancer (SDH-RCC): an aggressive example of the Warburg effect in cancer. Polish Journal of Pathology 201667 3-7. (https://doi.org/10.5114/pjp.2016.59227)

47 Williamson SR, Eble JN, Amin MB, Gupta NS, Smith SC, Sholl LM, Montironi R, Hirsch MS \& Hornick JL. Succinate dehydrogenasedeficient renal cell carcinoma: detailed characterization of 11 tumors defining a unique subtype of renal cell carcinoma. Modern Pathology 201528 80-94. (https://doi.org/10.1038/modpathol.2014.86)

48 López-Jiménez E, de Campos JM, Kusak EM, Landa I, Leskelä S, Montero-Conde C, Leandro-García LJ, Vallejo LA, Madrigal B, Rodríguez-Antona C et al. SDHC mutation in an elderly patient without familial antecedents. Clinical Endocrinology 200869 906-910. (https://doi.org/10.1111/j.1365-2265.2008.03368.x)

49 Dwight T, Mann K, Benn DE, Robinson BG, McKelvie P, Gill AJ, Winship I \& Clifton-Bligh RJ. Familial SDHA mutation associated with pituitary adenoma and pheochromocytoma/paraganglioma. 
Journal of Clinical Endocrinology and Metabolism 201398 E1103-E1108. (https://doi.org/10.1210/jc.2013-1400)

50 Gill AJ, Toon CW, Clarkson A, Sioson L, Chou A, Winship I, Robinson BG, Benn DE, Clifton-Bligh RJ \& Dwight T. Succinate dehydrogenase deficiency is rare in pituitary adenomas. American Journal of Surgical Pathology 201438 560-566. (https://doi. org/10.1097/PAS.0000000000000149)

51 Xekouki P, Szarek E, Bullova P, Giubellino A, Quezado M, Mastroyannis SA, Mastorakos P, Wassif CA, Raygada M, Rentia N et al. Pituitary adenoma with paraganglioma/pheochromocytoma (3PAs) and succinate dehydrogenase defects in humans and mice dehydrogenase defects in humans and mice. Journal of Clinical Endocrinology and Metabolism 2015100 E710-E719. (https://doi. org/10.1210/jc.2014-4297)

52 O'Toole SM, Dénes J, Robledo M, Stratakis CA \& Korbonits M. 15 years of paraganglioma: the association of pituitary adenomas and phaeochromocytomas or paragangliomas. Endocrine-Related Cancer 201522 T105-T122. (https://doi.org/10.1530/ERC-150241)

53 Niemeijer ND, Papathomas TG, Korpershoek E, de Krijger RR, Oudijk L, Morreau H, Bayley JP, Hes FJ, Jansen JC, Dinjens WNM et al. Succinate dehydrogenase (SDH)-deficient pancreatic neuroendocrine tumor expands the SDH-related tumor spectrum.
Journal of Clinical Endocrinology and Metabolism 2015100 E1386-E1393. (https://doi.org/10.1210/jc.2015-2689)

54 Ni Y, Seballos S, Ganapathi S, Gurin D, Fletcher B, Ngeow J, Nagy R, Kloos RT, Ringel MD, LaFramboise $\mathrm{T}$ et al. Germline and somatic SDHx alterations in apparently sporadic differentiated thyroid cancer. Endocrine-Related Cancer 201522 121-130. (https://doi. org/10.1530/ERC-14-0537)

55 Papathomas TG, Gaal J, Corssmit EP, Oudijk L, Korpershoek E, Heimdal K, Bayley JP, Morreau H, van Dooren M, Papaspyrou K et al. Non-pheochromocytoma/paraganglioma tumors in patients with succinate dehydrogenase-related pheochromocytoma-paraganglioma syndromes: a clinicopathologic and molecular analysis. European Journal of Endocrinology 2013170 1-12. (https://doi.org/10.1530/EJE-13-0623)

56 Renella R, Carnevale J, Schneider KA, Hornick JL, Rana HQ \& Janeway KA. Exploring the association of succinate dehydrogenase complex mutations with lymphoid malignancies. Familial Cancer 201413 507-511. (https://doi.org/10.1007/s10689-014-9725-4)

57 Santi R, Rapizzi E, Canu L, Ercolino T, Baroni G, Fucci R, Costa G, Mannelli M \& Nesi G. Potential pitfalls of SDH immunohistochemical detection in paragangliomas and pheochromocytomas harbouring germline $S D H x$ mutations. Anticancer Research 201737 805-812. (https://doi.org/10.21873/ anticanres.11381)

Received 29 June 2017

Revised version received 6 September 2017

Accepted 18 September 2017 